\title{
Myopic hydrogen vision
}

The Pew Center on Global Climate Change (www.pew.climate.org) found in a recent study that the transportation system of the United States alone generates more carbon dioxide emissions than the total economy of any other nation, except that of China. In this alarming context, President Bush's vision for hydrogen energy must offer some hope to lobbyists pushing alternative forms of energy — but the crucial question is whether enough money is being laid on the table.

The $\$ 1.2$ billion hydrogen-fuel initiative announced in January is one way for the Bush administration to demonstrate that it is serious about tackling the separate but related problems of global climate change and the United States' growing dependency on imported oil. The initiative includes $\$ 720$ million in funding over the next five years to develop the technology and infrastructures to produce, distribute and store hydrogen for use in fuel-cell systems and electricity generation. Combined with the FreedomCAR initiative to develop an affordable hydrogen-powered automobile by 2020 , it will add up to a total of $\$ 1.7$ billion over the next five years. But some analysts think that much more serious money - perhaps $\$ 100$ billion over 10 years - is needed to replace gasoline with gas at the fuel pumps.

Fuel cells can be used to run anything from a hospital to a mobile phone by combining hydrogen with oxygen to produce electricity and heat. Hydrogen is an ideal energy source for transportation because it burns twice as efficiently in a fuel cell as gasoline does in a combustion engine. The greatest attraction is that fuel cells can operate without generating emissions any more harmful than water vapour.

The Achilles heel of this technology, however, is that it is first necessary to find a source for hydrogen and then to store it. If renewable energy is used to split water into hydrogen and oxygen by hydrolysis, then the energy produced is genuinely emission-free. But if energy from a hydrocarbon such as coal or petrol is used, there will still be unwanted emissions - albeit less than those created when the same amount of hydrocarbon is burned in a combustion engine. That applies even if the route taken is steam reformation, in which the hydrocarbon is reacted with water vapour to liberate the hydrogen.

At first sight, therefore, it seems that Mr. Bush, much abused by environmentalists for his links with the fossil-fuel industry, is turning green. After all, the hydrogen technology he advocates seems to be the first serious challenge to the petroleum industry to emerge in a very long time. But environmentalists remain sceptical.

Cynics worry that the FreedomCAR programme is a public-private initiative that involves the 'big three'

PRESIDENT BUSH,ALONGWITH BIG BUSINESS, HAS PROMOTED HYDROGEN FUELAS ANALTERNATIVE TO OILFOR RUNNING THE UNITED STATES ECONOMY. THIS PROTOTYPE CAR MADE BY GENERAL MOTORS (WHOSEVICE PRESIDENT, LAWRENCE BURNS, IS PICTURED LEFT) IS POWERED BYA HYDROGEN FUEL CELL, AND THEREFOREWILL EMIT NOTHING BUT WATERVAPOUR. BUT ISTHEBUSH ADMINISTRATION REALLY SERIOUS ABOUT GIVING UP OIL? American car makers - Ford, General Motors and DaimlerChrysler — who seem to have little to gain from investing serious money in developing this technology while oil is so cheap. And some commentators immediately denounced the fuel-cell scheme as a way to divert attention from other important decisions, such as whether to tighten up the Corporate Average Fuel Economy law, which would require car companies to produce more fuel-efficient motors now rather than later. Others question Bush's overall commitment to 'green policies' because he has given support to measures such as the Clear Skies Initiative, a bill to regulate emissions from power plants that excludes carbon dioxide, and an energy bill that strongly boosts coal and nuclear power.

Scientists have also questioned the lack of university involvement in the hydrogen-fuel initiative. Indeed, when both houses of Congress gathered in March to review the programme, no academics were invited. Instead, committees asked representatives of companies like Shell and General Motors, together with environmental lobbyists, to participate in the debate. There are still many problems associated with the efficiency and reliability of fuel cells,

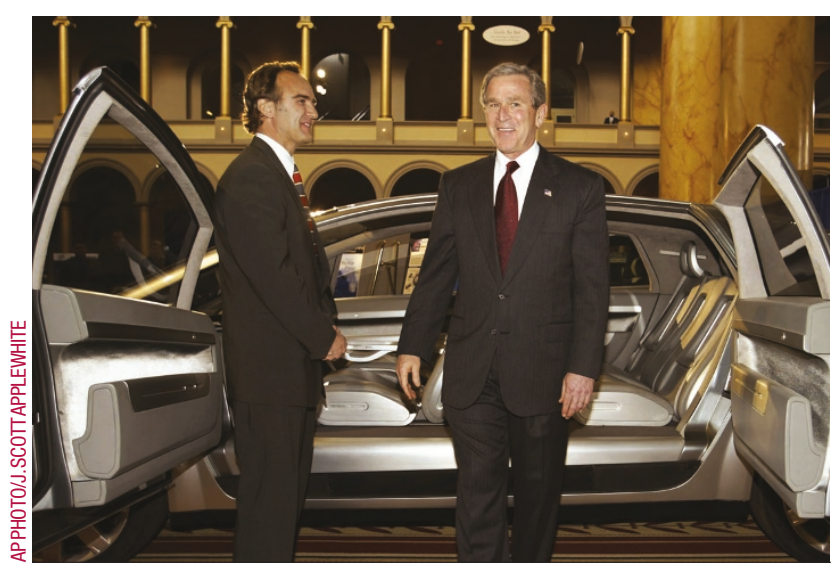
such as improving the properties of materials used for crucial components. These and other key issues, including hydrogen production and storage, will need to be solved at both a fundamental and engineering level before this technology can be successfully commercialized.

Nonetheless, if the rise of fuel-cell technology is to consign the internalcombustion engine to the dustbin of history, what is really needed is a coherent and long-term hydrogen strategy that takes advantage of existing infrastructures and generates public support for a hydrogen economy. If the Bush administration is really serious about implementing these crucial steps and achieving energy independence, it must do better than the $\$ 1.7$ billion it has so far allocated.

The hydrogen lobby has successfully persuaded the Texan oilman to give hydrogen technology a boost and to get big oil companies more involved, but its ambitions must not stop there. It is essential to convince everyone that this is only the first step. 